\title{
Being New Zealanders Now: Intricacies of Identity in a Multicultural New Zealand'
}

AMANDA GILBERTSON

The 2006 New Zealand census included the following question: 'Which ethnic group do you belong to?' A number of ethnic labels were provided and respondents were asked to select those that applied to them. Respondents could also select 'other' and write in the ethnic label(s) of their choice. In response to this question, 429,429 people wrote 'New Zealander' or 'Kiwi' under 'other', either as their sole response or in addition to other ethnic labels. When these responses are combined under the single category 'New Zealander' they constitute the third largest ethnic category in the country, representing $11.1 \%$ of the total population. ${ }^{2}$ Confusions of ethnicity and nationality aside, this raises some interesting questions about what it means to be a New Zealander today. Further fuel for such questions was provided by the increasing ethnic diversity recorded in the 2006 census. The significant rise in people identifying with Asian ethnic groupings led the Dominion Post to declare that there is no longer such a thing as a typical Kiwi. Apparently, New Zealanders no longer have anything in common, although we all 'cheer the All Blacks and douse food in tomato sauce'. ${ }^{3}$ Responding to these same figures, an article in the Press argued that 'the New Zealand way of life must be preserved'. ${ }^{4}$ Is there such a thing as a 'New Zealand way of life'? Can it be reduced to the All Blacks and tomato sauce? And how is it threatened by an increase in Asian immigrants?

There are a number of research strategies that could be employed in an attempt to answer the questions above. Years could be spent observing distinctive regularities in New Zealand behaviour and identifying the hidden rules governing them, and then attempting to extrapolate from this a set of national personality traits or inclinations. ${ }^{5}$ This paper, however, is less concerned with what 'New Zealanders' do and feel than with the meanings they attach to 'New Zealandness', 6 regardless of how far from actual practice these may be. It is not my intention to pin down a single, fixed national identity, but rather to discuss popular narratives or mythologies of New Zealandness through which national identities are constructed. 
Three strands of research will be drawn upon in this paper to explore how ordinary New Zealanders imagine their country, their culture and their community. I will begin by examining who identified as a New Zealander in the 2006 census and why. Although such people cannot be assumed to be the 'true' New Zealanders, their response to the ethnicity question in the census has generated much media, political and public discussion of the role of ethnicity in the nation. Furthermore, their characteristics and motivations provide some clues as to what kinds of people choose to apply the label 'New Zealander' to themselves. This will be followed by discussion of the ways some New Zealand-born Gujarati Indians talked about New Zealandness in interviews. I will focus particularly on the way these interviewees described processes of 'othering' that excluded them from automatic and full classification as New Zealanders. Finally, I will discuss how New Zealandness was described by New Zealand university students in survey responses. The dominant narratives evident in these strands of research suggest that, although 'New Zealand' is being continually reimagined in response to changes in the population and prevalent media and political discourses, particular concern is currently centred on the ethnic and cultural criteria for national belonging. ${ }^{8}$ At a time when New Zealanders, ranging from the Foreign Affairs Minister ${ }^{9}$ to suburban Auckland mums, ${ }^{10}$ are agitating over the supposed threat to national identity posed by increasing numbers of Asian immigrants, it is hoped that presentation of these narratives will encourage more informed and responsible debate about the shape of the nation.

\section{Ethno-New Zealanders}

'New Zealander' responses to the ethnicity question in the New Zealand census have been recorded for many years. Responses that have been classified in this way by Statistics New Zealand include similar terms such as 'Kiwi' and those that attach the terms 'New Zealander' or 'Kiwi' to other ethnicities, e.g. Samoan New Zealander or Indian Kiwi. The number of 'New Zealander' responses has increased in each census since 1986, but the extent of the increase recorded in 2006 , from $2.4 \%$ of the total population in 2001 to $11.1 \%$, was substantially larger than predicted by Statistics New Zealand. Determining who identified as a New Zealander in response to the 2006 ethnicity question is difficult, but the process reveals some interesting areas of concern in relation to both ethnic and national identity in New Zealand.

In their discussion of the 2006 census results, newspapers claimed that those who wrote New Zealander on their census forms used to be 'dismissed as rednecks'"1 who were 'brassed off at those uppity Maoris'. ${ }^{2}$ While this may well be an exaggeration, it does appear that it was widely accepted that 
'ethno-New Zealanders' - those who ethnically identify as New Zealanders - were people who might otherwise be described as 'New Zealand European' or 'Pakeha'. Up until the 2006 census, 'New Zealander' responses were classified in this way by Statistics New Zealand, and sociologist Avril Bell was clearly assuming this to be the correct classification when she referred to the large numbers of people identifying as 'New Zealanders' in the 1986 census as evidence of white New Zealanders' resistance to ethnic identities. ${ }^{13}$

There are a number of good reasons for such assumptions. Many New Zealanders of European descent find the ethnic label 'Pakeha' and its alternative, 'New Zealand European', problematic ${ }^{14}$ and may identify as 'New Zealanders' in rejection of these terms. In addition, as the dominant group in New Zealand, Pakeha/New Zealand Europeans ${ }^{15}$ have 'the power to go ethnically unmarked'. ${ }^{\prime 6}$ They are likely to conflate their culture and the national culture resulting in 'a primary (single?) cultural identification with the nation on the part of many white New Zealanders'. ${ }^{17}$ Nevertheless, a review of the 89,000 New Zealander responses to the ethnicity question in the 2001 census concluded that, as the majority of such responses were single responses (i.e. no other ethnicity was indicated), there were 'no identifying characteristics that would logically point to the group's inclusion with any other group.'.8 It was decided to separately count and output 'New Zealander' responses to the ethnicity question in the future.

In response to the overwhelming number of 'New Zealanders' in the 2006 census, newspapers have suggested three potential answers to the question of who these people might be (in addition to the possibility that they are 'rednecks'). One, they are New Zealanders of European descent who no longer identify with their European roots and so reject the New Zealand European category. Two, they are people from minority ethnic groups who wish to emphasise that they have a stake in this country. ${ }^{19}$ Or three, they are people expressing a reluctance to be divided along ethnic lines..$^{20}$ These suggestions relate to both the characteristics of those identifying as ethnoNew Zealanders, and the motivations behind the adoption of this label.

Although it is impossible to accurately ascertain what motivated such large numbers of people to write 'New Zealander' or 'Kiwi' in response to the 2006 census ethnicity question, a government report on the matter provides a well-reasoned argument as to what might have influenced them. ${ }^{21}$ In the weeks leading up to census night, public debate focused on the census ethnicity question. Part of this debate drew attention to the fact that 'New Zealander' responses were now going to be classified as a separate category. ${ }^{22}$ Awareness of this change may have made writing 'New Zealander' particularly appealing to white New Zealanders seeking an alternative to the terms 'Pakeha' and 'New Zealand European'. 
Another element in the debate involved a widely circulated email encouraging people who were not recent immigrants to identify as New Zealanders when asked for their ethnicity in the 2006 census:

Many of us however consider that we have been in New Zealand for long enough now that we should be able to claim that as who we are... regardless of where our ancestors may have come from many centuries ago or what the colour of our skin or shape of our face might indicate ... If we can get enough people to do this then maybe, just maybe, we can get the powers that be to sit up and recognise that we are proud of who we are and that we want to be recognised as such, not divided into sub-categories and all treated as foreigners in our own country. ${ }^{23}$

The origin of this email and the sectors of the New Zealand population it was targeted at are unknown. It could appeal to any one of the three potential types of 'New Zealander' respondents suggested by newspapers. However, discussion of the email in newspaper reports and internet blogs indicates that some assumed it reflected the desires of Pakeha/New Zealand Europeans to distance themselves from Europe and to reject ethnic classification. ${ }^{24}$ Interestingly, the only place that I could find what appears to be a full copy of the email was in a New Zealand 'e-zine for Indians abroad'. It was also suggested that the email might be politically motivated and reflect a rejection of race-based funding. ${ }^{25}$

Only slightly more information is available on the characteristics of these ethno-New Zealanders. Statistics New Zealand provides the following summary of the relevant demographics:

In the 2006 Census, those identifying as New Zealander:

- cover all ages

- are more likely to be male

- have higher regional proportions in the South Island than in the North Island

- are most often born in New Zealand.

In contrast to the total population those identifying as New Zealander:

- have an older median age

- have higher incomes

- are less likely to have Māori descent

- are healthier, in terms of smoking less than the total population

- are more likely to live in a rural area

- tend to have more educational qualifications. ${ }^{26}$

Statistics New Zealand pinpointed length of residence in the country as the most definite criterion for ethnic identification as a 'New Zealander'. An overwhelming majority of ethno-New Zealanders were born in New Zealand 
(93\% or 401,142 ) and most of those born elsewhere had lived in the country for more than ten years.

Despite the potential motivations discussed above, there is little conclusive evidence in the census results to suggest that these ethno-New Zealanders could be accurately classified as Pakeha/New Zealand European. The large decrease since the 2001 census in the number of people identifying as Pakeha/New Zealand European may indicate that this is the case, but most of this change can be accounted for by New Zealander responses being classified separately. The Statistics New Zealand report tells us: 'It seems likely that there has been a response shift to New Zealander from New Zealand European, decreasing the size of both the New Zealand European category and the European grouping in the 2006 census. However, some people may have recorded responses of New Zealander when they had previously identified with ethnicities in the Māori, Pacific peoples and Asian groupings, while some recorded New Zealander in addition to other groupings.'27

There were some similarities between the New Zealander category and people of European ethnicities in income and number of languages spoken, but little can be concluded from this. ${ }^{28}$ There is, however, a potentially significant difference between the New Zealander category and the total population in terms of the countries of birth of those born overseas. Of the ethno-New Zealanders who were born overseas, 58\% were born in England (9117), Australia (3117), South Africa (1443), Scotland (1074), the Netherlands (942) or the United States (843), whereas for the total population $54 \%$ of those born overseas came from England, the People's Republic of China, Australia, Samoa, India or South Africa. ${ }^{29}$ This suggests that those born in India, Samoa and the People's Republic of China were less likely to identify as New Zealanders in response to the ethnicity question in the 2006 census. While this difference may be accounted for by differences in length of residence in New Zealand between people from different source countries, these figures do raise an interesting question as to whether those who tend to be racially classified by others as white are more likely to identify as New Zealanders than those classified as Indian, Asian, or Pacific Islander.

The figures for respondents claiming multiple ethnicities give some indication of whether the 2006 New Zealander respondents were people from minority ethnic groups. Nearly $13 \%(55,364)$ of those who identified as New Zealander also identified with at least one other ethnic group, compared with just over $10 \%$ for the total population. ${ }^{30}$ As this was the first census in which multiple ethnicity rates were higher for the New Zealander category than for the total population, this might indicate an increasing desire among ethnic minorities to signify their identity as New Zealanders. It is not, however, possible to draw any conclusions as to the most appropriate ethnic labels for 
such people as the vast majority of New Zealander responses were single responses.

Academic research exploring the rejection of ethnic labels in favour of a New Zealand national identity has obtained varying results. For example, in survey research involving adults in a general sample and university students from Māori Studies and Psychology, James Liu found that 15 to 35\% (depending on the sample) of New Zealand European or Pakeha respondents "refused any ethnic labels and referred to themselves as "New Zealanders" or "just Kiwis"'. No Māori, Pacific or Asian respondents made similar claims. ${ }^{31}$ However, an earlier survey involving people who had identified themselves as 'New Zealand European/Pakeha' found that only $10 \%$ of the participants who said they never describe themselves as 'Pakeha' indicated that they did so because they 'prefer to be called a New Zealander'. Most rejected 'Pakeha' because the term was assumed to have negative connotations and/or because it did not adequately link them with their European or British ancestry. ${ }^{32}$

In research conducted as part of the Youth and Family Project, all research populations favoured the term New Zealander as something with which they could identify. ${ }^{33}$ This research involved a survey of high school students (aged 14 to 17) from a variety of ethnic backgrounds as well as their parents, and discussion groups with only the students. When asked 'Do you identify as a member of an ethnic group?', 56\% of survey respondents $(\mathrm{N}=739)$ answered 'no'. Such responses were particularly common amongst participants of British ancestry $(\mathrm{N}=509), 72 \%$ of whom indicated in the questionnaire that they did not identify as a member of an ethnic group. ${ }^{34}$ Although many respondents went on to identify with specific ethnic terms when prompted to do so later in the questionnaire, many discussion group participants suggested that they felt ethnicity was of little or no relevance to them in their everyday lives. The researchers concluded that, for the young people involved in the project (even those whose home lives were dominated by differences from the worlds of school, work and recreation), ethnicity, as participants conceived of it, played 'only a minor part in the social realities of their lives'. ${ }^{35}$ This suggests that a large number of those who identified as New Zealanders in the census may have done so simply because they did not believe ethnicity was a salient feature of their lives and did not feel a sense of identification with any ethnic group. This stance appears to be most prevalent among, but is not exclusive to, those of British descent.

Ultimately, efforts to identify the characteristics of those who gave New Zealander as their ethnicity in the 2006 census provide disappointingly inconclusive results. What has emerged as significant is both the relevance of birth or length of residence in New Zealand in claiming an identity as 
a New Zealander, and the weight that the popular media and the general public appear to have attached to determining the 'real' ethnicity of ethnoNew Zealanders. Underlying the debate appears to be uncertainty about the role ethnicity should play in the nation and a concern that New Zealanders of European descent may have, or may be perceived to have, the primary role in defining New Zealandness and primary rights in claiming it as their identity. ${ }^{36}$

\section{New Zealand-born Gujarati Indians on New Zealandness}

My interest in the debates surrounding the census is, in part, a result of research I conducted on the identities of members of a minority ethnic group in New Zealand. This research involved 15 semi-structured interviews with 16 New Zealand-born Gujarati Indians living in Wellington. ${ }^{37}$ Despite having been born and raised in New Zealand, some interviewees expressed concern about their own inclusion within general public understandings of New Zealandness.

All interviewees described themselves as New Zealanders, at least to some extent, and ail saw New Zealand as home: 'I do feel like a New Zealander a hundred percent. It's my home' (Savita, female, 24). Many expressed a very strong identity as New Zealanders. One participant stated that she felt 'disgusted' with herself when she inadvertently supported India at a hockey match: "half the game I was cheering for New Zealand and then all of a sudden I realised I was saying "go India" \{laughing\} . . . I thought "You little traitor you" (Jasmine, female, 40). Another participant told me that she always identified as a 'New Zealand Indian', and if that option was not available when filling in forms, she would write it in under 'Other'.

In explaining their own identities as New Zealanders, a wide variety of criteria for membership were mentioned by interviewees. Many made reference to being born and raised in New Zealand:

AMANDA: And what makes you a New Zealander?

HARSHA: The fact that I was born here and raised here and, I don't know, I guess I still have Kiwi in me as well.

Those participants who stressed the importance of being New Zealandraised, described their New Zealandness in terms of partaking in particular 'Kiwi' lifestyle practices:

I think it's a lifestyle thing where, you know, you have the ability to have a reasonable lifestyle. We're pretty lucky here. We've got everything on our doorstep, everything's available. We have rugby, beer and jandals and beaches and all that kind of outdoorsy activities that everyone here loves doing. So yeah I think that's for me, I think it means most about being a New Zealander (Arun, male, 46). 
In contrast, those who placed more emphasis on their New Zealand citizenship by birth tended to suggest that a New Zealand 'culture' did not exist:

There's not a New Zealand thing, there's not like a check list, a set of things that are a New Zealander ... when I think of a New Zealander I just think of somebody who lives here and that New Zealand is their home (Savita, female, 24).

When I think of New Zealand culture, what is New Zealand culture? I don't really think there is much of a culture for New Zealand. I really don't. Because I think it's generic in a way. That's not fair, I take it back. I don't want to say like the fish and chips and the beer gut and stuff like that. That's not really culture at all. I don't consider that as culture (Meenakshi, female, 42).

These descriptions of 'New Zealand culture' mirror many of the accounts produced by participants in both the Youth and Family Project (described above) and in research on Hindu identity amongst Indians in Wellington conducted by Sharmila Bernau. Many of Bernau's interviewees discussed New Zealand mainly in terms of the location they happened to be in at the present, and suggested there were no meaningful differences between New Zealand culture and the culture of other western nations. ${ }^{38}$ Likewise, many participants in the Youth and Family Project used the term New Zealander not so much to refer to an identity, but as a general acknowledgement of their county of birth and residence. Participants also struggled to explain what is distinctive, special and particular about being a New Zealander. References were made to 'a set of prosaic features such as sun, sea, surf and beer' (features somewhat analogous to Arun's description of 'outdoorsy activities that everyone here loves doing'), but participants had difficulty expanding an idea of New Zealand culture beyond these traits. Researchers concluded that because participants had not consciously grown up as New Zealanders, they lacked an ethnic-like sense of being New Zealanders. That is, their cultural New Zealandness was implicit in their everyday lives. ${ }^{39}$

Despite making multiple claims to inclusion under the term 'New Zealander', all interviewees in my research implicitly suggested that they were limited in their ability to completely adopt a New Zealand identity. They consistently differentiated between themselves and other Indians, ${ }^{40}$ on one side, and New Zealanders or Kiwis, on the other. In addition, all used the words New Zealander, Kiwi, English and European interchangeably, thereby equating New Zealander with New Zealand European. For example, when asked whether she felt like a New Zealander, Aparna replied, 'I talk English and I fit in with English people'. Similarly, many participants in the Youth and Family Project said that they believed the terms Kiwi or 
New Zealander were interchangeable with the term Pakeha, a label usually associated with New Zealanders of European descent. ${ }^{41}$

Some interviewees in my research were more explicit in suggesting they were unable to be full New Zealanders because they were not White/ European/Pakeha New Zealanders: 'I could never call myself a New Zealander because, I don't know, maybe because I see a New Zealander as a European ... I've never thought of myself as just a New Zealander. l've always thought New Zealand Indian' (Meenakshi, female, 42). Those who questioned their ability to be full New Zealanders expressed the issue in terms of being racially and culturally different from the native-born whites who dominate New Zealand society.

A few interviewees described being identified by others as Indian based on their physical appearance and indicated that this precluded an identity as a full New Zealander:

Generaily when people see me they normally take me as being an Indian that's not from here . . . because of the colour of the skin etc. and the way I look ... I said to my friends, 'If you didn't know me and if you saw me on the street, how would you see me? Would you know that I was a New Zealander or would you see me as an Indian?' And they basically said, 'You're an Indian as far as we know until we talk to you' (Bhaskar, male, 40). ${ }^{42}$

This suggests that, for the New Zealand-born Gujaratis in this study, their racial classification functions as a kind of "master status" as it is the aspect that is widely used by others to define them. Their New Zealand identities need to be actively conveyed to others in the form of a New Zealand accent and participation in New Zealand activities and lifestyles: 'That's why I go out a lot. That's why I mix with a lot of non-Indian people to show them that, hey, we're not different' (Bhaskar, male, 40).

Together with a dominant racial norm, many participants expressed the idea that European norms and cultural practices dominated New Zealand society: 'If you're in India, you do what the Indians do, what the Gujaratis do, right? And when you're here you do what the Europeans are doing. You can keep your culture as well and, you know, mix with the other culture' (Karuna, female, 63). Only three participants briefly mentioned Māori in their discussions of New Zealandness and little significance was accorded to it: 'I think also just the usual things like the Mãori culture, pavlova, jandals, state housing' (Jasmine, female, 40). The Youth and Family Project indicated similar roles for European and Māori culture in defining 'New Zealand culture'. As in my research, participants often excluded Māori from consideration when talking about New Zealandness but made occasional reference to Māori customs which were appropriated to New Zealand 
identity. ${ }^{44}$ Similarly, in research conducted as part of the International Comparative Project of Ethnocultural Youth (ICSEY), around half of participants indicated that they thought about both European and Māori culture when they thought about New Zealand and New Zealand culture, but one in three thought only about New Zealand European and none thought only of Māori culture. ${ }^{45}$ This appears to support Avril Bell's suggestion that, although 'Maori culture is the national culture when distinctiveness and exoticism are called for', Pakeha/New Zealand European culture is the national culture 'in terms of providing the pervasive, commonsense underpinnings for the ordering of social life'. ${ }^{46}$

Many participants in my research suggested that the term 'New Zealander' referred to certain cultural norms which did not correlate with their cultural experiences:

DIPANKAR: It wouldn't be honest \{laughs\} to put New Zealander . . . if there's a line for you to put other and then just write, I do . . .

AMANDA: What is it about New Zealander that you aren't?

DIPANKAR: \{pause\} European \{with conviction\}. Even though we all know that it's a multicultural society and blah blah blah, it's yeah . . .

AMANDA: What is it about being European though?

DIPANKAR: I feel the dominant cultural thing is overtly European

AMANDA: Culturally you don't feel like you do things that are European?

DIPANKAR: Yeah sure, yeah, totally.

AMANDA: But you don't identify as a New Zealander?

DIPANKAR: Always as Indian . . . I don't think being a New Zealander embraces all the cultural ideals and all the identities of everybody in it ... When you watch things on TV, like the regular household, that kind of stuff and then when you're not that, of course you feel different.

A nother interviewee, Lata, suggested that her participation in and understanding of 'New Zealand culture' contributed to her sense of being a New Zealander, but, as her participation and understanding were limited, so too was her sense of belonging. She explained that while it is predominantly the judgements people make based on her physical appearance that make her feel like less of a New Zealander, not participating in what she perceives to be New Zealand activities 'illustrates it a bit more for me'.

It is important to note, however, that many participants described their exclusion from 'New Zealand culture' as having a source within the Gujarati 'community', ${ }^{47}$ due to the definition of Indianness in terms of its difference 
from 'Kiwiness'. ${ }^{48}$ Several of the examples of 'Indian culture' given by participants were described with reference to non-Indians:

In my non-Indian friends I see people that don't go and see their grandparents from one month to the next or you know don't even know who their first cousins are or things like that whereas with us, you know, my brother got married last year and we struggled to cut his list down to 300 people from our side (Savita, female, 24).

Some participants also described a process whereby they defined as Indian anything that they saw as separating them from other New Zealanders. For example, for many participants the restriction of their social activities became part of their definitions of Indianness. All participants described an 'Indian' system of protocol in which certain activities were deemed appropriate and others were deemed inappropriate. This system was depicted by participants as a mechanism of boundary maintenance that played a significant role in defining 'Indianness' within the Gujarati 'community'. Participants suggested that unacceptable activity was defined as New Zealand or Western and appropriate activity was defined as Indian:

They do say 'our way' 'their way' . . Making the distinction . . . Like 'white society does things differently to us'. It wasn't always stated, but there's a lot of 'we, Indian, we, Indian', that language is definitely there (Lata, female, 25).

A few participants described how the expectations of the Indian community prevented them from participating in some 'New Zealand' activities and thus prevented them from being full New Zealanders. In this way Indianness and New Zealandness were constructed as mutually exclusive, making identification as both an Indian and New Zealander difficult. This perhaps explains the absence of Māori from participants' narratives. When defining Indianness and New Zealandness in terms of their difference from each other, conceiving of New Zealanders as anything other than a homogeneous group would complicate the process enormously. New Zealandness is therefore associated only with European New Zealandness in terms of both racial and cultural norms.

Although the majority of interviewees in this study identified rather unquestioningly as New Zealanders, the ways in which they discussed New Zealandness suggested that 'full' New Zealanders differed, as they imagined things, both culturally and racially from themselves. All implied, and a few explicitly stated, that being a New Zealander demands, at least to some extent, European ancestry and that Pākeha/New Zealand Europeans feel a sense of 'proprietary claim ${ }^{49}$ to being the 'real' New Zealanders. Those who did question their own New Zealandness felt themselves to be racially classified as foreign by others and only partially included in cultural norms. 
Many participants in the Youth and Family Project thought being born in New Zealand gives more legitimacy to New Zealandness. They suggested that this legitimacy is further enhanced by being able to count a number of generations since their ancestors first settled here. ${ }^{50}$ While my participants expressed similar ideas, they suggested that racial and cultural deviation from the perceived norm may override birth and generational claims to New Zealandness. The difficulty of identifying as a New Zealander was exacerbated by the definition of Indianness within the Gujarati 'community' in terms of its difference from New Zealandness.

\section{Survey}

In order to gather a wider range of ideas about what it means to be a New Zealander, I conducted a survey with first year anthropology students and students in a social sciences pre-undergraduate bridging course. Students were asked about 'typical New Zealanders' and 'New Zealand culture', as well as their own identification as New Zealanders. Of the 178 respondents, $86 \%$ were aged between 17 and 20 and there were more than twice as many females as males. The vast majority of participants $(81 \%)$ indicated that they were born in New Zealand.

Survey respondents were asked to state their ethnicity and, as no tick boxes were supplied, they could write any combination of ethnic labels they identified with. In keeping with the census, multiple ethnicities were recorded for some respondents, so when all ethnicities are calculated they add up to more than $100 \%$. In response to the ethnicity question, $38 \%$ wrote New Zealand European or Pākeha, 16\% identified as European, 14\% identified as New Zealanders or Kiwi, and 13\% wrote Māori. Multiple responses were given by $11 \%$ of participants. The 'New Zealander' responses to the questionnaire were for the most part in alignment with those from the 2006 census and reveal little more about who might identify as an ethno-New Zealander. Of the 25 participants who responded to the ethnicity question with 'New Zealander' or 'Kiwi', four gave multiple responses: 'NZ/Maori', 'New Zealander (European)', 'New Zealand/Philippine' and 'NZer, German, Dutch'. Most (21) stated that they were born in New Zealand and those who had not been born in New Zealand had lived here for between six and 19 years.

In addition to the ethnicity question, participants were asked whether they identified as New Zealanders and why. Positive responses to this question were given by $86 \%$ of participants (153). The most common reasons given for identifying as a New Zealander were: born here (64), spent whole/most of life here (53), grew up here (42), parents/family from here (29), and participation in/engagement with New Zealand culture or lifestyle (24). ${ }^{51}$ The most common reasons given for not identifying as a New Zealander 
or being unsure about identifying as a New Zealander were: not having lived here long enough, and identification with other ethnicities/nationalities. Of the 144 participants who were born in New Zealand, 93\% wrote that they identified as New Zealanders. Only one said that she did not identify as a New Zealander. The remaining nine New Zealand-born participants indicated uncertainty about their identity as New Zealanders, the most common reason being identification with other ethnicities/nationalities. As the objective of this paper is to explore the meanings New Zealanders attach to New Zealandness, I have included only the responses of those who indicated that they identified as New Zealanders in my analysis of the remaining questions.

Much uncertainty was expressed in response to the second major question of the questionnaire: 'Do you think there is such a thing as a typical New Zealander? If so, describe your typical New Zealander. ${ }^{52}$ Many participants stated that they did not believe there was such a thing and explained this with reference, either to the variation within New Zealand's population, or to the inherent uniqueness of all individuals. Only one third $(\mathrm{N}=51)$ of participants who identified as New Zealanders gave a clear 'yes' response to this question. However, many who responded negatively or with uncertainty described a 'stereotype' or 'archetype', a recognised idealised image which they differentiated from their own experiences and understandings of being New Zealanders: 'Not really, New Zealand is such a diverse range of cultures, I think there are however stereotypes of the "gidday mate I farm sheep and wear gumboots" type of kiwi' (female, 'New Zealand pakeha', 18). ${ }^{53}$

Participants who identified as New Zealanders referred to a wide range of characteristics, objects and activities in responses to the typical New Zealander question. The most frequently referred to were laidback (19); rugby (16); farmers or farming (16); drinking alcohol, particularly beer (16); and Kiwiana clothing such as stubbies or shorts, jandals, gumboots, singlets and swandris (15). Reference to specific kiwiana food, such as Marmite and pavlova were also quite common, as were personality traits such as friendliness, innovation or resourcefulness, being rough or rugged, being family oriented, being down to earth and being accepting of other cultures. Also mentioned by three or more participants were blokes or men, ${ }^{54}$ sheep, the outdoors or nature, the beach, barbecues and sports. However, by far the most common response to the 'Do you think there is such a thing as a typical New Zealander?' question, was 'no' with some reference to diversity (43).

Participants were more comfortable with a notion of 'New Zealand culture' than they were with the idea of a 'typical New Zealander'. When asked 'Do you think there is such a thing as New Zealand culture?', two thirds of those who identified as New Zealanders responded positively. The most 
common reason given by those who disagreed with this notion was that the diversity of 'cultures' evident in the country overrode a monolithic, singular New Zealand culture. As participants were equally as likely to write that there was no New Zealand culture because of this cultural diversity as they were to say that this diversity is New Zealand culture, little importance can be attached to whether participants answered yes or no. Instead, as with the previous question, data was collected on those things that were referred to by the largest numbers of participants in response to the 'New Zealand culture' question. Most common was a general reference to a mix of cultures, cultural diversity or multiculturalism (43), followed by specific reference to Māori culture (35), and specific reference to European, British or Pākeha culture (17). Being laidback (13) and drinking alcohol (12) were the fourth and fifth most frequently mentioned traits. Polynesian or Pacific Island culture was also specifically referred to by quite a few participants. Sports, barbecues, haka and kapa haka, rugby, the beach or ocean, the outdoors, agriculture or farming, pavlova, the importance of the land, kiwis, being friendly and being clean and green were all mentioned by three or more participants.

As the above discussion illustrates, there was considerable overlap between responses to the typical New Zealander question and responses to the New Zealand culture question. Combining the results from both questions reveals some interesting trends in the meanings these New Zealanders attach to New Zealandness. The following were referred to by the largest numbers of participants: Māori culture (35), laidback (29), drinking alcohol, particularly beer (26), rugby (20), farmers or farming (20), British, European or Pākeha culture (17), Kiwiana clothing (16), friendly (12), the outdoors or nature (11), blokes or men (10), barbecues (10), and sports other than rugby (10). ${ }^{55}$ But the standout figure is that nearly half of participants (76) made some reference to cultural diversity or multiculturalism in their responses (this does not include participants who referred specifically to Māori, Pākeha and/or Pacific cultures).

As is very often the case with questionnaires, these results must be interpreted with caution. The participant group is clearly unrepresentative of New Zealand society generally. In addition, survey questions of this nature will always be interpreted in different ways by different respondents, and it is possible that a number of these young social science and anthropology students gave what they perceived as correct or desired responses. With little pressure to reflect on their own opinions, participants may also have simply reproduced normative responses. Nevertheless, this survey provides some indication of popular narratives (or myths) of New Zealandness. These narratives differ in interesting ways from previous descriptions of New Zealand identities. Although (appropriated?) Mâori culture and the laidback, beer-drinking, rugby-loving farmer wearing his gumboots, shorts and singlet 
still feature prominently, other mythologies, particularly egalitarianism, a relationship with the land, and the 'clean green' image, were mentioned by surprisingly few participants. These narratives appear to have been displaced by, among other things, an increased attention to drinking and, particularly, cultural diversity. The frequent references to alcohol may well reflect the bravado of young students in their first weeks of university, but are probably also a result of recent media campaigns drawing attention to New Zealand's problematic 'binge-drinking culture'. The overwhelming emphasis on cultural diversity probably reflects the increasing ethnic diversity of New Zealand's population, increasing media and political attention to this diversity, increasingly public celebration of cultural festivals, and efforts to include awareness of cultural difference in school curricula. It seems possible that New Zealand's egalitarian myth, ${ }^{56}$ which proclaimed socio-economic equality of individuals, is being transformed into a rhetoric of cultural/ethnic equality or ethno-egalitarianism. ${ }^{57}$ The comments of Gujarati participants above, however, suggest that, as with socio-economic egalitarianism, ethnoegalitarianism exists primarily at the level of discourse and does not reflect real ethno-cultural equality.

\section{Conclusion}

The three research strands discussed above indicate uncertainty about both 'New Zealanders' and 'New Zealand culture'. Familiar icons of New Zealandness - laidback blokes, rugby, farmers, the outdoors, barbecues, etc. - continue to form a part of how New Zealanders talk about their nation. But this perhaps reflects the enduring pervasiveness of these images and the ease with which they can be reproduced (particularly in survey responses), rather than a sense amongst participants that these accurately represent the nation. As Claudia Bell has argued, the 'same essential package of mythologies and symbols can be wheeled out whenever required ... Identity imagery is so readily recognised, that it reads instantly as "New Zealand", whenever and wherever it appears' ${ }^{58}$ These ready-made symbols appear in the research alongside hesitation about whether New Zealanders share common characteristics and are united by a common culture. Those participants who attempted to explain their hesitation suggested that diversity overrides commonalities and that a national culture requires a distinctiveness that New Zealand lacks. Others attempted to locate 'New Zealandness' in more 'civic' criteria such as residence, citizenship and abiding by the laws of the country.

All strands of research indicated concern for the degree to which popular notions of 'New Zealanders' and 'New Zealand culture' are inclusive of all New Zealanders. In particular, debates surrounding the 2006 census, and the accounts of Gujarati New Zealanders in my own research, indicated 
concern that New Zealanders of European descent are perceived as the racial and cultural norm. ${ }^{59}$ Although 'others' may be accepted as full members of New Zealand society, they may be perceived as not possessing the racial and cultural credentials for such acceptance to be automatic or full fledged. They remain irrevocably 'ethnic', unable to 'fade into a majority backcloth'.60 In contrast, reference to cultural diversity was very common in university students' discussions of New Zealandness in their questionnaire responses. While this may simply reflect the desire of social science students to appear more cosmopolitan, it may also suggest that conceptions of New Zealandness are becoming more accommodating of ethnic diversity. It is difficult, however, to ascertain whether this accommodation represents genuine tolerance and mutual recognition, or is limited to rhetoric and symbolic gestures.

The concerns expressed in the research discussed above in many ways reflect a tension between ethnic and civic models of the nation. Although nationalism by definition seeks commonality, the commonalities associated with civic models of the nation - allegiance to shared legal and political principles - are more accessible to a range of 'others' than those associated with ethnic models - shared descent, language, religion and so on. Both civic and ethnic models of the nation can involve notions of a "national culture', the difference being that civic models envisage a national culture into which anyone can integrate. ${ }^{61}$ The deracialisation of immigration entry requirements in the 1987 Immigration Act indicated a move, in principle, towards civic nationalism in New Zealand, but core civic citizenship rights have been slow to replace a belief in a Pākeha /New Zealand European 'ethnic core'. The process has been necessarily complicated by bicultural discourses that invoke an ethnic model of a bi-national community. ${ }^{62}$ These tensions play out in discussions over whose culture is/should be the national culture and who are/should be the 'real' Kiwis. It seems that many New Zealanders are attempting to imagine an inclusive culture for themselves, but most existing points of reference are tied to earlier ethnic models of Pākeha New Zealandness.

Although multiculturalism appears to be a useful counter-discourse to an exclusive ethnic model of the nation, the concept presents problems of its own. Several scholars have identified an increase in multicultural discourse and policy in recent decades, but many have expressed concern over the degree to which this offers a positive and substantive counterpoint to monocultural Pākeha a New Zealandness. ${ }^{63}$ Over a decade ago, Claudia Bell identified 'a slowly increasing portrayal of New Zealand as multicultural by the image-makers', but argued that this 'does not for a moment mean a redistribution of power amongst diverse cultures' ${ }^{64}$ Concern has been raised over the extent to which this is a multiculturalism in which 'minority and 
immigrant groups add spice and colour to the mainstream society', ${ }^{65}$ as cultural distinctions are compartmentalised in order to divide the nation into ethnic categories which 'reproduce the old racialised and ethnified faultlines they are purportedly designed to replace'. ${ }^{66}$ A perception of ethnic groups as fundamentally and definitively unique, and an understanding of 'culture' as a collection of distinctive traits, diverts attention from structural inequalities and discourages recognition of cultural commonalities. 'New Zealander' (read New Zealand European) continues to be positioned as the non-ethnic 'normal' in relation to which all ethnic minorities are constructed. This perspective is encouraged by current political and media discourses of multiculturalism that focus on standardised forms of depoliticised difference - dress, dance, festivals and food - and suggest that 'ethnicity' is the concern of minorities. ${ }^{67}$ Although being 'ethnic' in New Zealand has many positive associations, the consistency of 'othering' involved encourages marginalisation.

Ultimately there is concern that although multiculturalism offers a possibility for challenging existing structures, it is an ambiguous concept that can be used to control group differences and maintain the power of the dominant grouping. ${ }^{68}$ Discourses of multiculturalism construct national identity as being in process and enable negotiation over the content of the 'national culture' ${ }^{69}$ But they also tend to construct 'cultures' as whole, bounded and isolated, to direct difference into safe channels, to ignore heterogeneity within each 'culture' or 'ethnic group', and to construct binary relations between 'ethnic groups' and 'New Zealand society' so that immigrants and their descendants are forever marginalised ${ }^{70}$ As New Zealand's population becomes increasingly diverse it seems likely that nationalist narratives will gradually move away from images of 'Pakeha purity'?1 However, if these narratives are to be truly inclusive of all New Zealanders, there will have to be some recognition of the multifaceted, situational nature of identities and some understanding of 'culture' and 'ethnicity' that allows ethnic and national identities to easily exist alongside each other.

The New Zealand government recently pledged its commitment to 'continuing to make our national identity a priority' and 'investing further in celebrating our culture and values. ${ }^{72}$ As the above discussion has indicated, what exactly 'our culture and values' are remains a matter of contestation. While discourses of multiculturalism and, particularly, biculturalism have challenged images of a Pākeha/New Zealand European 'ethnic core', uncertainty remains over the power of ethnic minorities to shape, and be included in, the way the nation is imagined. This is, in part, a result of popular constructions of culture and ethnicity, but also reflects a long history of tension between mono-, bi-, and multi-cultural models of New Zealand. The narratives of participants suggest a desire to imagine that New Zealanders share more than abstract political and legal principles but 
a dissatisfaction with banalities such as tomato sauce and the All Blacks. The development of nationalisms that are consistent both with the ethnic diversity of New Zealand's population and with Treaty principles are likely to be facilitated by serious and sustained discussion about national identity in New Zealand, critical engagement with the concept of multiculturalism, and careful consideration of its relationship to biculturalism.

1 A much earlier version of this paper was presented as part of the Stout Research Centre's 'Watching the Kiwis' seminar series, Victoria University of Wellington, 26 April 2008. 1 gratefully acknowledge the helpful comments of my friends and colleagues who read this article - David Pearson, Peter Howland, Nick Jones and Tamsyn Gilbertson.

2 Statistics New Zealand, 'Profile of New Zealander Responses, Ethnicity Question: 2006 Census', Wellington, 2007, p.1, http:/www.stats.govt.nz/NR/rdonlyres/EA0F8124-619C -47B3-ADB7-CBB28F44AE85/0/Profileof NewZealanderCensus2006.pdf.

3 'No such thing as a typical Kiwi', Dominion Post, 7 December 2006.

4 'Census points to challenges ahead for a multicultural New Zealand', Press, 9 December 2006.

5 This was the strategy adopted by Kate Fox in her study of the English, Watching the English: The Hidden Rules of English Behaviour, London, 2004.

6 I use the term 'New Zealandness' throughout this article to refer to (perceived) characteristics or qualities of New Zealanders and 'New Zealand culture".

7 See James H. Liu, Tim McCreanor, Tracey McIntosh and Teresia Teaiwa, 'Introduction: Constructing New Zealand Identities', in James H. Liu, Tim McCreanor, Tracey McIntosh and Teresia Teaiwa, eds, New Zealand Identities: Departures and Destinations, Wellington, 2005, p.14.

8 Stephanie Taylor and Margaret Wetherell, 'Doing National Construction Work: Discourses of National Identity', Sites, 30 (1995), pp.74-77.

9 Rt Hon Winston Peters. 'New Zealand's identity crisis - colony or nation?', An address to Grey Power North Shore, 23 May 2003, http://www.nzfirst.org.nz/content/display_item .php?t=1\&i=1018; NZPA, 'Winston Peters' memorable quotes', October 18 2005, http:// www.theage.com.au/news/world/winston-peters-memorable-quotes/2005/10/18/1129401 225653.html.

10 Claudia Bell, Inventing New Zealand: Everyday Myths of Pakeha Identity, Auckland, 1996, pp.186-7.

11 Rebecca Palmer, 'Who are we', The Dominion Post, 7 December 2006, edition 2, p.2.

12 Linley Boniface, 'Time that we came to our Census', Waikato Times, 14 December 2006.

13 Avril Bell, "We're Just New Zealanders': Pakeha Identity Politics', in Paul Spoonley, Cluny Macpherson, and David Pearson, eds, Nga Patai: Racism and Ethnic Relations in Aotearoa/New Zealand, Palmerston North, 1996, p.145.

14 Avril Bell. pp.144-49. David Pearson and Jeffrey Sissons, 'Pakeha and Never Pakeha', Sites, 30 (1995), pp.64-80.

15 Although I have stated that many people find the terms 'Pakeha' and 'New Zealand European' problematic and do not use them to define themselves, I have decided to use them in this article as the most suitable terms for describing majority group members in New Zealand. It is difficult to accurately pinpoint who is included within the Pàkeha /New Zealand European category. The term 'Pakeha' has been said to refer to all non-Maori New Zealanders, but is most often used to refer to white New Zealanders, particularly those of Anglo-Celtic origin who were born in New Zealand or have lived 
in the country for a long time. It is the latter meaning of Pakeha that I refer to when I use both terms in this article.

16 James H. Liu, 'History and Identity: A System of Checks and Balances for Aotearoa/New Zealand', in James H. Liu, Tim McCreanor, Tracey McIntosh and Teresia Teaiwa, eds, New Zealand Identities: Departures and Destinations, Wellington, 2005, p.78.

17 Avril Bell, p.149.

18 Deborah Potter, 'Who are New Zealanders?', Statistics New Zealand, Wellington, 2003.

19 Boniface.

20 Palmer.

21 Statistics New Zealand, p.3.

22 Government Statistician, '2006 Census Ethnicity Question Clarified', 28 February 2006, Press Release: Statistics New Zealand; Simon Collins, "Kiwi" a dinkum response for next Census', nzherald.co.nz, 13 January 2006; Julie Middleton, 'Email urges "New Zealander" for Census', nzherald.co.nz, I March 2006.

23 Brian D'Silva, 'Are you a Kiwi?', The Global Indian, Issue 17, March 2006, p.14, http:// www.theglobalindian.co.nz/uploads/Mar06TGl.pdf.

24 "The email appeal seems to be "a statement of independence from Europe or the mother country", says the president of the Population Association, Ward Friesen. People may be trying to reject "the connection with colonialism - I guess the word European is problematic" - or "trying to pretend we're all the same, but it's unrealistic".' Middleton, 'Email urges 'New Zealander' for Census'; '[M]y initial reason for hating that tick other: new zealander email was that had something like: being a NZ european is like being made to feel like a foreigner in our own country', posted by 'homeperm', at 'From the Morgue', 8 March, 2006, http://www.additiverich.com/morgue/archives/001242.html.

25 Middleton.

26 Statistics New Zealand, p.1.

27 Statistics New Zealand, p.7.

28 Statistics New Zealand, pp.13, 19.

29 Statistics New Zealand, p.12.

30 Statistics New Zealand, pp. 9-10.

31 Liu, 'History and Identity', p.78.

32 Pearson and Sissons, pp.68-69.

33 This research was conducted in the Department of Anthropology at Victoria University between 1994 and 1998. Youth and Family Project, http://www.vuw.ac.nz/yfp; James Urry, 'Growing Up Non-Ethnic: "Everyone's People", unpublished working paper, Wellington, 2004, p.15.

34 Urry, pp.1-3.

35 Urry, p.22.

36 Similar issues have been identified in literature on Australia. See, for example, Miriam Dixon, The Imaginary Australian: Anglo-Celts and Identity - 1788 to the present, Sydney, 1999; James Forrest and Kevin Dunn, “'Core" Culture Hegemony and Multiculturalism: Perceptions of the Privileged Position of Australians with British Backgrounds', Ethmicities, 6, 2 (2006), pp.203-30.

37 Interviewees were recruited and interviewed between July and September of 2006. My participant group consisted of nine women and seven men, with a fairly even age spread from teens to sixties. All interviewees had at least one parent who had been born outside New Zealand, and many had two non-New Zealand-born parents. However, most had multiple generations of their family currently living in the country. Some interviewees in this study were related to each other, but no two interviewees were living in the same houschold, nor had they done so for many years. The interviews consisted of 
open-ended questions and lasted between about 45 minutes and just under three hours. Fourteen participants were interviewed individually and two siblings were interviewed together. Amanda Gilbertson, 'Symbolic ethnicity and the dilemmas of difference: Talking Indianness with New Zealand-born Gujaratis', MA thesis, Victoria University of Wellington, 2007.

38 Sharmila Bernau, 'Imagining community in Godzone - Hinduism and identity amongst Indians in Wellington: an oral history project', MA thesis, Victoria University of Wellington, 2006, p.115.

39 Urry, p.19.

40 Despite all participants in this study being Gujarati, this paper examines their management of Indian, rather than Gujarati, identities. Although many interviewees explicitly stated their distinctiveness as Gujaratis from other Indians, most used the words 'Gujarati' and 'Indian' fairly interchangeably throughout interviews and all focused predominantly on their status as 'Indians' in discussions of forming an ethnic and cultural identity in New Zealand. The interchangeable use of the terms 'Indian' and 'Gujarati' amongst Gujaratis has been noted in other studies of Indian New Zealanders and there are a number of reasons for this focus on national rather than regional identity. For Gujaratis. a conflation of 'Gujarati' and 'Indian' is encouraged by the historic dominance of this regional grouping in Wellington (and to a large extent in New Zealand), which has led to Indianness being largely defined in terms of Gujaratiness. In addition, interviewees consistently expressed the notion that 'identity' was of concern to them because of their 'difference' from other New Zealanders and that their 'Indianness' - rather than their regional, religious or caste identities - was the primary source of this 'difference'. A pan-Indian identity is also encouraged by the lack of familiarity with regional, religious and caste differences and identities within the category Indian amongst non-Indian New Zealanders. While I refer to the 'Indianness' of interviewees in this study, I do not intend to suggest that findings can be readily applied to non-Gujarati Indians in New Zealand.

41 Urry, p.16.

42 Kasanji's second generation Wellington Gujarati interviewees also felt that they were 'not a part of New Zealand and its social milieu, because of their distinct physical appearance'. Lalita Kasanji, 'The Gujaratis in Wellington: the study of an ethnic group', MA thesis, Victoria University of Wellington. 1982, p.141.

43 Merton in M.C. Waters, Black Identities: West Indian Immigrant Dreams and American Realities, Cambridge, MA, 1999, p.5.

44 Urry, p.18.

45 Colleen Ward and En-Yi Lin, 'Immigration, Acculturation and National Identity in New Zealand', in James H. Liu, Tim McCreanor, Tracey Mclntosh and Teresia Teaiwa, eds, New Zealand Identities: Departures and Destinations, Wellington, 2005, p.163.

46 Avril Bell, p.149.

47 I use 'community' throughout this paper as a 'native term'. This term was attached to both 'Gujarati' and 'Indian' and was used to mean different things in different contexts. However, most interviewees used the term to refer to an essentially Gujarati community comprised of their families and members of the Wellington Indian Association and Wellington Indian Sports Club, as well as other Gujaratis seen at events such as weddings.

48 For a discussion of participants from minority ethnic groups constructing their ethnic identities through comparison with 'Kiwis', see Jane Roscoe, 'Immigrant Nation: Television Documentary and the Narration of National and Cultural Identities in New Zealand, Sires, 34 (1997), pp.87-8. 
49 Blumer 1958 in M. Tuan, 'Neither real Americans nor real Asians? Multigeneration Asian ethnics navigating the terrain of authenticity', Qualisative Sociology, 22, 2 (1999), p.123.

50 Urry, p.17.

51 The three major questions of the questionnaire were open ended. Participants were not asked to list or rank those things that came to mind, but it was decided that the most appropriate way to analyse responses was to create a list of things mentioned in responses and to record the number of participants who referred to each item on the list.

52 For an interesting discussion of the history of the search for a New Zealand 'type', see Keith Sinclair, A Destiny Apart: New Zealand's Search for a National Identity, Wellington, 1986, pp.80-91.

53 See Claudia Bell, pp.I0-11 for a discussion of participants in other studies of New Zealand identity differentiating between idealised mythologies of New Zealandness and their daily experiences of living in New Zealand.

54 Most participant responses in this category made specific reference to 'blokes', but those responses that clearly involved a description of a male rather than a female New Zealander were included as well.

55 These results contrast quite markedly with the results of ethnographic and semiotic research on New Zealand identity conducted by FCB consumer researchers and advertising professionals. Although both studies found an over-representation of male icons of identity, FCB researchers found nature to be a far more dominant icon of national identity than was found in this study. In fact, FCB researchers argue that anti-Asian sentiment in New Zealand might arise from the perception that Asian immigrants and Asian New Zealanders do not engage with or 'do' nature in the same way that other New Zealanders might imagine themselves to. Rita M. Denny, Patricia L. Sunderland, Jacqueline Smart and Chris Christofi, 'Finding Ourselves in Images: A Cultural Reading of Trans-Tasman Identities', Journal of Research for Consumers, 8 (2005).

56 Bill Willmott, 'Introduction: Culture and National Identity', in David Novits and Bill Willmott, eds, Culture and Identity in New Zealand, Wellington, 1989, p.3; Claudia Bell, p.12.

57 Peter Howland, personal communication, 2008.

58 Claudia Bell, p.184.

59 See also Willmott, p.10; Claudia Bell, p.13.

60 David Pearson, personal communication, 2008.

61 David Pearson, 'The ties that unwind: civic and ethnic imaginings in New Zealand', Nations and Nationalism, 6, 1 (2000), pp.92-3.

62 Pearson, 'Ties that unwind', pp.104-5. See also Augie Fleras, 'Working Through Differences: The Politics of 'Isms' in Aotearoa', New Zealand Sociology, 13, 1 (1998), pp.62-96.

63 Sinclair, p.261. David Pearson, 'Rethinking Citizenship in Aotearoa/New Zealand', in Paul Spoonley, Cluny Macpherson and David Pearson, eds, Tangata Tangata: The Changing Ethic Contours of New Zealand, Southbank, Vic., 2004, pp.302-8; Arvind Zodgekar, 'The Changing Face of New Zealand's Population and National Identity', in James $\mathrm{H}$. Liu, Tim McCreanor, Tracey Mclntosh and Teresia Teaiwa, eds, New Zealand Identities: Departures and Destinations, Wellington, 2005, p.152.

64 Claudia Bell, p.187.

65 Tim McCreanor, "'Sticks and stones may break my bones ..." Talking Pakeha Identities', in James H. Liu, Tim McCreanor, Tracey Mclntosh and Teresia Teaiwa, eds, New Zealand Identities: Departures and Destinations, Wellington, 2005, p.59.

66 Pearson, 'Rethinking Citizenship', pp.307-8. 


\section{Journal of New Zealand Studies}

67 See Ward and Lin, p.162.

68 Pnina Werbner, 'The Politics of Multiculturalism in the New Europe', in Barbara Saunders and David Haljan, eds, Whither Multiculturalism? A Politics of Dissensus, Leuven, 2003, p.50; Pearson, 'The ties that unwind', p.96; Fleras, pp.65-66.

69 Werbner, p.58; Jon Stratten and len Ang, 'Multicultural Imagined Communities: Cultura] Difference and National Unity in the USA and Australia', in David Bennett, ed., Multiculural States: Rethinking Difference and Identity, London, 1998.

70 Stratten and Ang.

71 Claudia Bell p.195.

72 'Budget 2007: National Identity', 'beehive.govt.nz: The official website of the New Zealand Government', 17 May 2007, http:/www.beehive.govt.nz/feature/budget +2007 +national+identity. 